\title{
Th9 ląstelių transkripcijos faktoriuc STAT6 ir PU.1 vaidmuo sergant astma
}

Ieva Janulaityte், Simona Lavinskienè

LSMU MA Pulmonologijos ir imunologijos klinika

Reikšminiai žodžiai: astma, Th9 ląstelès, transkripcijos faktoriai, IL-9, STAT6, PU.1.

Santrauka. Astma yra lètinè kvejpavimo takų uždegimo liga, kuriai būdinga praeinanti bronchų obstrukcija bei bronchų hiperreaktyvumas. Astmą sukelia tiek aplinkos, tiek genetiniai veiksniai bei ju tarpusavio sąveika. Th9 ląsteles yra naujai aptikta $\mathrm{CD}^{+}{ }^{+} \mathrm{T}$ ląstelių subpopuliacija, kuri išskiria dideli kieki IL-9. Naivieji CD4+ T limfocitai, veikiami TGF- $\beta$ ir IL-4, diferencijuojasi j Th9 ląsteles. Šie citokinai veikia PU.1 ir STAT6 transkripcijos faktorių raišką. Transkripcijos faktoriai reguliuoja /19 geno raišką. Tačiau dar nẻra atlikta pakankamai tyrimų, nustatyti IL-9 ir jo transkripcijos faktorių STAT6 ir PU.1 sąsajas, kurios gali turèti j̨akos alerginès astmos patogenezei.

Astma - lètinè kvèpavimo takų uždegimo liga, kurios procese dalyvauja ịvairios uždegimo ląstelès ir jų išskiriami citokinai bei chemokinai. Tai daugiakomponente liga, kuri apima tiek genetinius, tiek aplinkos veiksnius bei jų tarpusavio sąveiką. Dèl lètinio uždegimo didèja bronchų reaktyvumas ịvairiems dirgikliams. Ligą paskatina aplinkos antigenai, kaip antai: namų dulkių erkès, žiedadulkès, gyvūnų pleiskanos, kailis ar maistas, kurie paprastai neveikia sveikųjų [1]. Ligai būdinga išplitusi ¿̇vairaus laipsnio, dažniausiai grįžtamoji, kvèpavimo takų obstrukcija, pasireiškianti dusulio ir (ar) kosulio priepuoliais, ypač naktị ir paryčiais, praeinančiais savaime ar gydant. Liga dažniausiai pasireiškia dar vaikystejje. Astma serga apie $300 \mathrm{mln}$. žmoniu pasaulyje [2]. Alerginis rinitas yra astmos rizikos veiksnys - 80 proc. asmenų, sergančiu astma, kartu diagnozuojamas ir alerginis rinitas [3].

Sergant astma, būdinga uždegimo ląsteliụ, $\mathrm{CD} 4^{+} \mathrm{T}$ ląsteliụ subpopuliacijų infiltracija ł̇ bronchụ sienelę, padidejjusi citokinų IL-4, IL-5, IL-9 ir IL-13 gamyba $[4,5]$, struktūriniai bronchų sienelès pokyčiai ir išvešèjusios gleivių liaukos. Uždegimas apima visą bronchų medį, taip pat ir smulkiuosius kvejpavimo takus bei plaučiu parenchimą. Odos dūrio mėginiai rodo padidejjusią IgE (imunoglobulino E) koncentraciją. IgE sukeltas jautru- mas yra ankstyvosios ir vèlyvosios fazės reakcijos priežastis.

Astma sergančių ligonių kvẻpavimo takų gleivinèje randamas didesnis kiekis limfocitu (daugiausia $\mathrm{CD} 4^{+} \mathrm{T}$ ląstelių), eozinofilų, plazminių ir dendritinių, taurinių ląstelių, būdinga židininè fibrozè, epitelio deskvamacija, sustorèja savasis gleivinès dangalas, progresuoja lygiụju raumenų hipertrofija. Ištyrus paūmejusia alergine astma sergančių asmenų biopsinę ir autopsinę medžiagą, nustatyta dar didesnè uždegimo ląstelių, ypač $C D 4^{+}$ir $\mathrm{CD}^{+} \mathrm{T}$ ląsteliụ, eozinofilų, neutrofilụ ir alveolinių makrofagu infiltracija.

Kvėpavimo takus dengia ir apsauginị barjerą antigenams sudaro daugiasluoksnis stulpinis epitelis, tarpląstelinès jungtys, transmembraniniai adhezijos baltymai. Sergant astma, apsauginè kvejpavimo takų epitelio funkcija sutrinka, todèl padideja pralaidumas antigenams. Skiriamos dvi astmos uždegimo fazès: ankstyvoji ir vèlyvoji. Ankstyvajai uždegimo fazei būdingas atsakas atsiranda per pirmąsias minutes nuo antigeno patekimo. Šią reakciją sukelia histaminas ir putliųjų ląstelių bei bazofilų išskirtų granulių baltymai. Šie granulių baltymai sukelia gamybą leukotrienų, prostaglandinų ir citokinų, kurie aktyvina putliąsias ląsteles. Suaktyvintos putliosios ląstelès gamina IgE, kuris dirgina nervų galūnèles ir 
sukelia lygiųjų raumenų susitraukimus. Alerginei astmai yra būdingas lygiụjų raumenų susitraukimas - bronchų spazmas. Taurinès ląstelès gamina daug gleivių, endotelio ląstelès sukelia vazodilataciją, ir išsivysto edema. Vèlyvajai uždegimo fazei būdingas atsakas prasideda tik po 8-12 valandų. Ankstyvojoje fazèje išskirti citokinai, leukotrienai ir prostaglandinai skatina epitelines ląsteles išskirti tarpląstelines adhezijos molekules. Šios molekulès veikia kaip chemoatraktantai, dèl to padideja chemotaksis $\mathfrak{i}$ antigeno patekimo vietą, kur priplūsta uždegimo ląstelių: granuliocitinių ir fagocitinių ląstelių bei $\mathrm{CD}^{+}$ T ląstelių. Th2 limfocitai išskiria IL-4, IL-5, IL-6, IL-10, IL-13 ir taip moduliuoja B ląstelių sukeltą humoralinị imuninị atsaką, skatina IgE sintezę, aktyvina eozinofilus. IgE ir IL-5 (interleukino 5) koncentracija periferiniame kraujyje padideja [6]. Aktyvintų ląstelių išskirti mediatoriai, net tik kaupiasi uždegimo vietoje, bet ir žaloja kvėpavimo takų audinius, sukelia lètinị uždegimą. Besitęsiantis lètinis uždegimas ilgainiui sąlygoja remodeliaciją - struktūrinius kvėpavimo organų pokyčius: kvėpavimo takų epitelio, liaukinių bei lygiụjų raumenų ląstelių išvešejjimą, fibrozę.

Bronchų biopsinès medžiagos tyrimai rodo, kad struktūriniai kvėpavimo takų pokyčiai atsiranda dar ankstyvojoje ligos stadijoje. Asmenų, sergančiu lengvesnès formos alergine astma, bet nevartojančių inhaliuojamųjų gliukokortikoidų, kvejpavimo takų pokyčiai yra gerokai didesni negu vartojančių inhaliuojamuosius gliukokortikoidus [7].

\section{T LĄSTELINIS IMUNITETAS}

$\mathrm{T}$ limfocitai yra pagrindinès specifinio imuniteto atsako ląstelès, svarbios gynybinei kvẻpavimo sistemai. Plaučiai nuolat sąveikauja su chaotišku įvairių antigenų mišiniu, tačiau tik kai kuriems potencialiems patogeniniams mikroorganizmams neutralizuoti ir sunaikinti reikalingas specifinis imuninis atsakas. Kai yra specifinis atsakas, i kvėpavimo takus patekusi antigeną specializuotos antigeną pateikiančios ląstelès pristato T limfocitams. Šie atpažįsta tik tą antigeną pateikiančių ląstelių pristatytą baltymo antigeną, kuris yra susijungęs su I ar II klasès pagrindine audinių suderinamumo komplekso MHC molekule. T limfocitai turi ir ląstelès paviršiuje esančius baltymus, vadinamus CD (angl. cluster of differentiation), rodančius diferenciacijos laipsnị, aktyvumą bei funkciją. Priklausomai nuo šių molekulių, skiriamos dvi didelès T limfocitu populiacijos: CD4 ${ }^{+} \mathrm{T}$ limfocitai pagalbininkai ir CD8+ T limfocitai žudikai. T limfocitai turi gauti antrąji stimuliuojantị signalą iš antigeną pristatančių ląstelių ar kitų uždegime dalyvaujančių ląstelių paviršinès molekulès, kad galètų diferencijuotis ì $\mathrm{T}$ limfocitus pagalbininkus: Th1, Th2, Th9, Th17 ir Treg.

\section{TH9 LACSTELE்S}

T limfocitai pagalbininkai (Th1-Th2) literatūroje pirmą kartą paminèti 1986 m. [8, 9]. Naivieji CD4+ T limfocitai turi potencialą diferencijuotis i skirtingas subpopuliacijas, Th1, Th2, Th17 bei Treg [10], kurios atitinkamai apsaugo nuo specifinio patogeno. Vis dèlto nebuvo aišku, ar IL-9 gamina IL-4 išskiriančiosios Th2 ląstelès ar yra atskira T limfocitų pagalbininkų subpopuliacija, išskirianti IL-9. Tuo metu nebuvo galimybių atskirti IL-4 nuo IL-9 gaminančiu ląsteliu [11]. 2008 m. mokslininkai nustatè, kad IL-4 ir TGF- $\beta$ (transformuojantis augimo faktorius $\beta$ ) yra tam tikros CD4 ${ }^{+}$ $\mathrm{T}$ limfocitu subpopuliacijos augimo ir diferenciacijos veiksniai. Buvo nustatyta, kad diferencijuoti $\mathrm{CD}^{+} \mathrm{T}$ limfocitai gamina didelị kiekị IL-9, todèl nauja T limfocituc pagalbininkų subpopuliacija pavadinta Th9 ląstelèmis [12-15].

IL-9 jungiasi prie IL-9R (IL-9 receptorių) ant ląstelių membranų esančių taikinių. IL-9R sudarytas iš ligandui specifinès $\alpha$ grandinès ir paprastos $\gamma$ grandinès. IL-9R $\alpha$ grandinè skirta surišti IL-9 stipriu afinitetu, tačiau signalinis kelias negalimas be $\gamma$ grandinès aktyvinimo. Paprastoji $\gamma$ grandine reaguoja ir su IL-2, IL-4, IL-7, IL-15, IL-21. Signalo perdavimas priklauso nuo Janus kinazès ir STAT transkripcijos faktorių signalinių kelių, svarbių tolesnei uždegimo eigai.

Atlikti lyginamieji tyrimai su pelių ir žmogaus Th9 ląstelèmis. Tiek žmogaus, tiek pelès organizmuose Th9 ląstelès negamina kitoms Th subpopuliacijoms būdingu

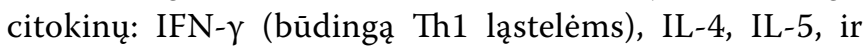
IL-13 (būdingụ Th2 ląstelèms) ar IL-17 (būdingą Th17 ląstelèms) [16]. Tyrimais su pelèmis buvo įrodyta, kad IL-4 ir TGF- $\beta$ reikalingi Th9 ląsteliu diferenciacijai $[12,17]$. Ta pati mokslininku grupe įrodè, kad, siekiant atskirti CD4+ $\mathrm{T}$ limfocitų subpopuliacijas, ląsteles turi suaktyvinti tam tikri citokinai. Kiekvienas citokinas geba aktyvinti specifini transkripcijos faktorių, reikalingą $\mathrm{T}$ limfocituc pagalbininku subpopuliacijų diferenciacijai ir tolesnei jų citokinų gamybai.

Pirmiausia IL-9 buvo aptiktas pelèse, kur jis veikia kaip stiprus nuo antigenu priklausomas $\mathrm{T}$ limfocituc [18-20] ir putliụjų ląstelių augimo faktorius ir sukelia padidejusią gleivių gamybą ir išsiskyrimą, taip pat kvejpavimo takų remodeliaciją, būdingą alerginiam kvẻpavimo takų uždegimui. Buvo manoma, kad IL-9 pagrindinis šaltinis yra Th2 ląstelès, putliosios ląstelès ir eozinofilai [21]. Nustatyta, kad IL-9 kiekis kraujyje padideja sergant helmintoze, Hodžkino limfoma, alergine astma [22]. Šis reguliacinis citokinas stabdo $\mathrm{CD}^{+} \mathrm{T}$ limfocitu limfokinu gamybą ir skatina $\mathrm{CD}^{+} \mathrm{T}$ limfocituc proliferaciją. IL-9 raiška gerokai padidejusi astma sergančių asmenų, gydomų alergiją blokuojančiais vaistais, plaučiuose [23]. Eksperimentuose su peliu in vivo modeliais buvo nustatyta, kad IL-9 raiškos padidejjamas susijęs su patogeninemis infekcijomis, kaip antai: Leishmania major, Trichuris muris, Schistosoma mansoni [24-26]. 
Atlikti tyrimai patvirtina [15], kad Th1 ląstelių išskiriami IFN- $\gamma$ ar IL-27 gali stabdyti IL-9 gamybą T naiviosiose ląstelèse TGF- $\beta$ ir IL-4 aplinkoje [27]. Vis dar tiriama, kaip IFN- $\gamma$ ir IL-27 stabdo Th9 ląsteliu formavimąsi ir IL-9 gamybą per transkripcijos faktoriaus STAT1 signalinị kelią [16]. Uždegime dalyvaujantys IL-1b, IL-6, IL-10, IFN- $\alpha$, IFN- $\beta$ ir IL-21 skatina IL-9 gamybą CD4+ $\mathrm{T}$ ląstelèse. Th9 ląstelès, kurios gamina IL-9 ir IL-10, yra pagrindiniai žymenys nustatant alergini uždegimą pelèms, tačiau žmogaus Th9 ląstelès IL-10 negamina (1 pav.).

Naujausiu tyrimu duomenimis, IL-9 geba slopinti Th2 limfocitu apoptoze per IL-2 ir IL-9R $\alpha$ signalinius kelius. IL-9 poveikis kvėpavimo takų epitelinių ląsteliụ funkcijoms buvo tirtas in vivo ir in vitro. Transgeninis IL-9 pelèms didino eotaksino, makrofagų uždegimo baltymo- $1 \alpha$ ir monocitu chemotaktinio baltymo 1,3 ir 5 raišką $[28-30]$.

\section{TRANSKRIPCIJOS FAKTORIAI}

Eukariotinių ląstelių polimerazių aktyvumui būtini papildomi baltymu veiksniai, kurie jungiasi prie promotoriaus ir sužadina transkripciją. Transkripcijos faktoriai - tai baltymai, veikiantys RNR polimerazès gebą nurašyti tam tikrą geną bei reguliuojantys ląstelių DNR transkripciją. Tipiškas transkripcijos faktorius turi specifinę DNR seką atpažistantị bei prie jo prisijungiantị domeną ir vieną ar daugiau transkripciją aktyvinančiu domenų, kuriais gali sąveikauti su kitais branduolio baltymais.

Eukariotu transkripcijos faktoriai, kurie veikia kartu su RNR polimeraze II, skiriami $\mathfrak{i}$ dvi grupes: pagrindinius transkripcijos faktorius ir genus valdančius baltymus. Pagrindiniai transkripcijos faktoriai yra būtini sužadinti taisyklingą transkripciją. RNR polimerazė II jungiasi mažiausiai su šešiais transkripcijos faktoriais: TFIID, TFIIA, TFIIB, TFIIE, TFIIF ir TFIIH [31], kurie susirenka prie promotoriaus í vieną kompleksą - PIC (preiniciacijos kompleksas). Pirmasis komplekso baltymas, kuris jungiasi su specifinemis DNR sekomis ir prie kurio jungiasi kiti transkripcijos faktoriai, yra TFIID. Jis padeda PIC „susirinkti“, sąveikaudamas su promotoriaus TATA dèžute. TFIID yra sudarytas iš TBP (TATA-binding protein) ir daugelio su TBP susijungusiu faktoriu TAFs. TBP jungimasis TATA děžutès srityje suardo DNR spiralę, ir tada išsivynioja dvigrandè DNR. Pagrindiniai transkripcijos veiksniai yra labai konservatyvūs (2 pav.).

\section{TH9 LĄSTELIŲ TRANSKRIPCIJOS FAKTORIAI STAT6 IR PU.1}

Ankstesniais tyrimais nustatyta, kad Th9 ląsteliu diferenciacijai svarbiausi transkripcijos faktoriai yra STAT6 ir PU.1 (3 pav.). Jie atsakingi už Il9 geno transkripciją,

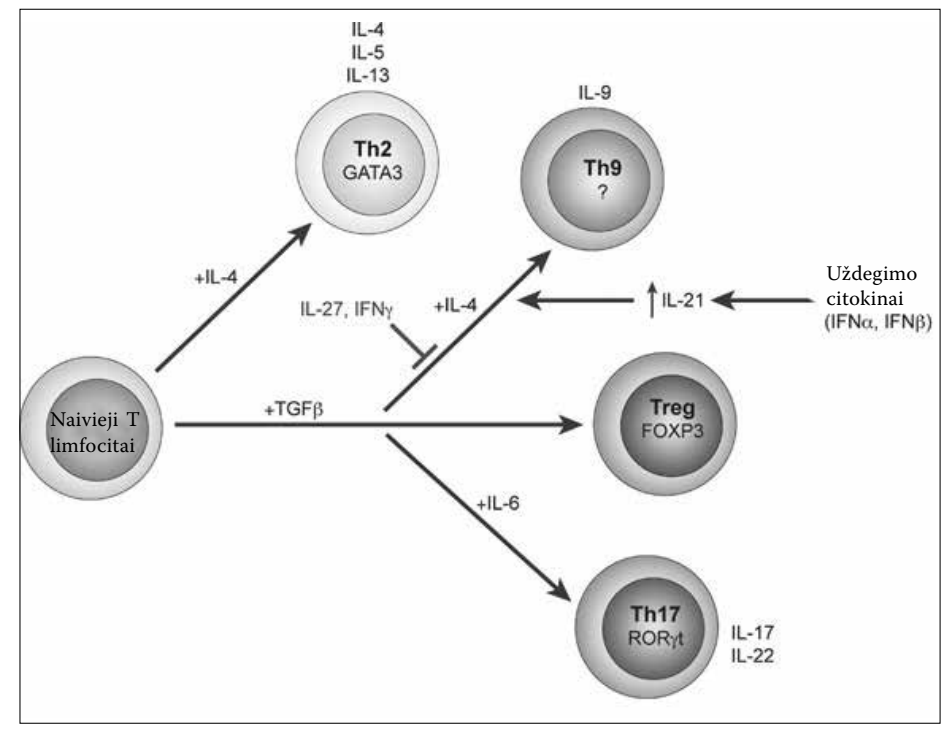

1 pav. TGF- $\beta$ vaidmuo Th ląsteliu diferenciacijoje

dèl to padidèja IL-9 raiška alergine astma sergančių asmenu periferiniame kraujyje. Tyrimai rodo, jog, stingant IL-4, TGF- $\beta$ skatina Treg vystymąsi, o kai stinga TGF- $\beta$, IL-4, skatina Th2 ląsteliu vystymąsi. IL-4 signalui veikiant ląstelès membranoje esančius IL-4 receptorius (IL-4R), STAT6 transkripcijos faktoriai reikalingi IRF4, GATA3 suaktyvinti, o T-bet, Foxp3 slopinti ir potencialiems kitiems faktoriams veikti, kaip transkripcijos faktoriu tinklo dalis. IRF4 ir GATA3 signalinis kelias sužadina $I l 9$ geno raišką ir T-bet ir Foxp3 signalinius kelius, kurie $I l 9$ geno raišką slopina, todèl ji didejja, nes pašalinami slopinantys veiksniai.

STAT (angl. signal transducer and activators of transcription) yra neseniai identifikuotos transkripcijos faktorių šeimos nariai, kurie aktyvina geno transkripciją kaip atsaką í citokinus [32]. STAT yra slaptasis (latentinis) citoplazminis baltymas, kuris yra aktyvuojamas citokinụ receptoriu tirozino kinaziu JAK (Janus) fosforilizacijos po citokinu poveikio. STAT fosforilizacija leidžia dimerizuotis atskiriems STAT baltymams per jų SH2 domenus. Po dimerizavimosi STAT dimeras yra funkcionuojantis ir gali migruoti tiesiai ị branduolị, kur jungiasi prie DNR ir tiesiogiai aktyvina transkripciją kaip atsaką i citokinus. STAT šeimos narių $\mathrm{NH}$-terminalinis galas yra konservatyvus ir sudarytas iš 130 aminorūgščių; šis regionas reikalingas dimerizuotų STAT molekulių tetramerizacijai - tik tada jos geba kooperuotai jungtis prie DNR promotorių, esant daug potencialiu STAT atpažinimo sričiu. Stat6 turi kelias egzistuojančias izoformas, priklausomai nuo to, kurioje ląsteleje arba audinyje randama. Dvi natūraliai žmonėms atsirandančios izoformos (Stat6b ir Stat6c) Stat6 mRNR turi alternatyvu splaisingą. Stat6b izoforma turi deleciją amininiame gale visame Stat6 baltyme, todèl trūksta dalies SH2 domeno, o dèl to sunkejja dimerizacija. STAT6 veikiantis IL-4 yra 


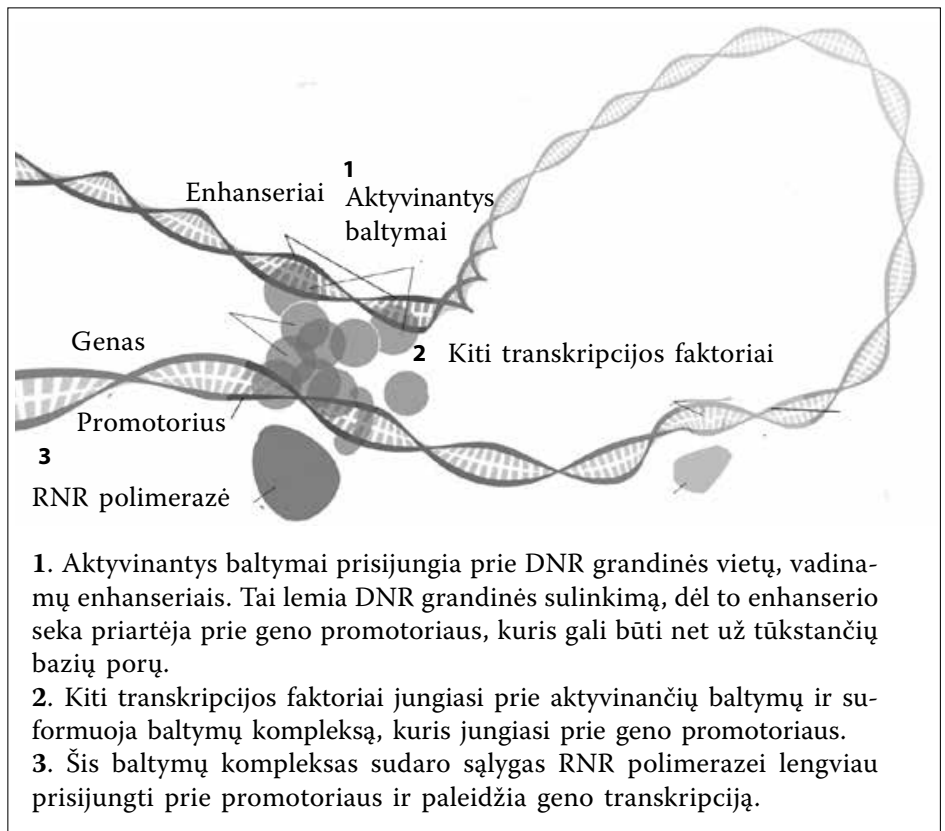

2 pav. Eukariotinių ląstelių transkripcijos faktoriai

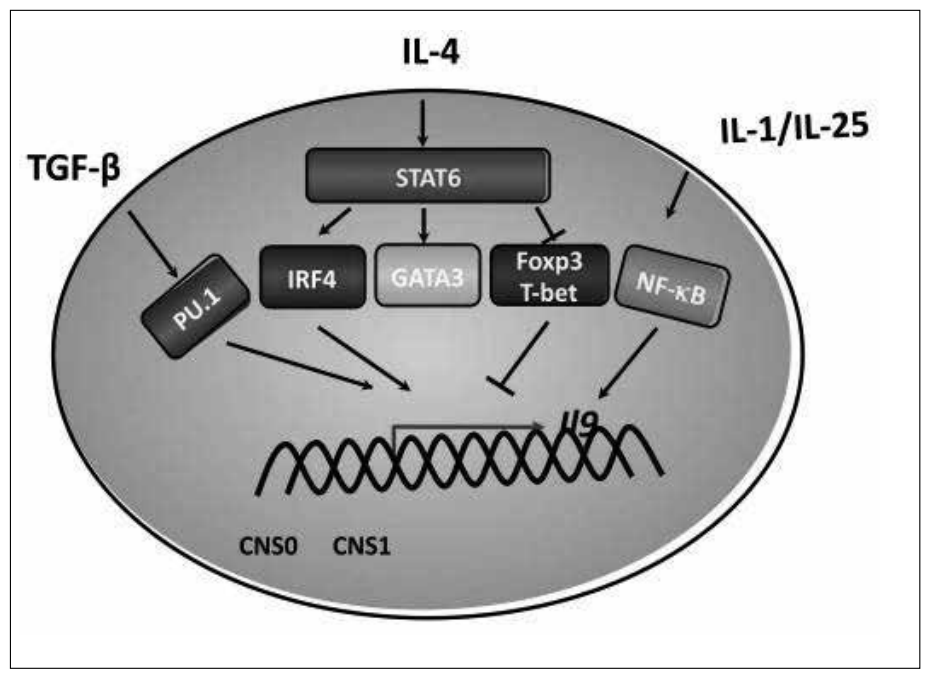

3 pav. Th9 ląsteliu transkripcijos faktoriu tinklas

Transkripcijos faktoriai PU.1 ir STAT6, atitinkamai veikiami TGF- $\beta$ ir IL-4 signalų, aktyvina GATA3, IRF4 bei PU.1 raišką ir reguliuoja $I l 9$ geno raišką Th9 ląstelèse.

citokinas, veikiantis limfocitụ proliferaciją, gyvybingumą, genų raišką ir diferenciaciją.

Kitas transkripcijos faktorius yra PU.1. Jis yra ETS šeimos transkripcijos faktorius, turintis daugeli funkcinių domenų. ETS homologinis DNR rišimosi domenas yra C-terminaliniame gale, o rūgščiu bei gliutamino turtingas domenas yra $\mathrm{N}$-terminiame gale - jie abu veikia kaip transaktyvacijos domenai. PU.1 yra vienas iš transkripcijos faktorių, reikalingu Th9 ląsteliụ vystymuisi, jungiasi tiesiogiai prie $I l 9$ geno promotoriaus $[17,33]$. Th9 ląstelèse PU.1 raiška yra didesné nei Th2 ląstelèse [10]. PU.1, remiantis atliktais tyrimais, padidina histonu acetilinimą $I l 9$ geno lokuse per tiesiogini kon- taktą su histonų acetiltransferazėmis (HAT), tuo pačiu slopinant histonų deacetilazés aktyvumą padideja PU.1 priklausomo IL-9 gamybą [34]. Atliktas tyrimas Il9 geno lokuso chromatino modifikacijoms tirti naiviuosiuose $\mathrm{T}$ limfocituose juos veikiant tam tikra citokinu aplinka, büdinga Th1, Th2, Th9, Th17 ląsteliụ diferenciacijai. Analizè atlikta imunoprecipitacijos metodu. Nustatyta, kad suminis $\mathrm{H} 3$ bei $\mathrm{H} 4$ histonu acetilinimas dviejose Il9 konservatyviose nekoduojančiose srityse $\mathrm{H} 3 \mathrm{~K} 9$ bei H3K18 buvo didesnis Th9 ląstelių subpopuliacijoje, lyginant su kitomis. IL-9 alergija sergančiu asmenų kraujyje gaminosi daug daugiau nei alergija nesergančiụ kraujyje. Iš peliụ, kurioms stigo PU.1, išskirtos ir augintos naiviosios $\mathrm{CD}^{+} \mathrm{T}$ ląstelès Th9 ląsteliụ aplinkoje gamino mažesnị kiekị IL-9 nei normalios [33].

PU.1 sudaro kompleksą su Gcn5 ir taip stabdo Gcn5 raišką, dèl to sumažejja IL-9 gamyba. Be to, Gcn5 poveikis IL-9 gamybai yra specifinis, kaip ir IL-10, ir IL-21, dviejų papildomų citokinu, kuriuos gamina Th9 ląstelès, tačiau nèra paveiktos sumažejusios Gcn5 raiškos. Pelèms, turinčioms sąlyginę Sfpi1 alelio, koduojančio PU.1, mutaciją, T ląstelèms specifinè delecija sąlygojo mažesnę IL-9 gamyba in vitro ir in vivo - dèl to sumažèjo alerginis uždegimas. IL-9 gamyba gali būti sužadinta ir Th17 bei Treg ląstelèse $[35,36]$, kuriu diferenciacijai reikalingas TGF- $\beta$. TGF- $\beta$ yra svarbus apoptozei. Apoptozé, užprogramuota ląsteliu mirtis, yra svarbi determinantẻ tiriant uždegimo procesus, kai uždegime dalyvaujančiu ląstelių išgyvenimo laikas, veikiant ịvairiems citokinams, ilgèja [37]. TGF- $\beta$ sergant astma veikia per PU.1 signalini kelią ir sukelia T limfocitu pagalbininku diferenciaciją, reguliuoja ląstelès ciklą, imuninès sistemos veiklą, be to, šis morfogenas laikomas vienu iš vèžinių ligų žymenų. Imuninèje sistemoje jis reguliuoja T ląstelių Foxp3 raišką ir veikimą.

\section{APIBENDRINIMAS}

Th9 ląstelès yra neseniai atrasta $\mathrm{T}$ limfocitu subpopuliacija, svarbi alerginès astmos patogenezei, kvejpavimo takų remodeliacijai. Th9 ląstelès yra pagrindinès ląstelès, gaminančios IL-9. IL-9 stimuliuoja ląsteliu proliferaciją, stabdo apoptozę, sukelia bronchų hiperreaktyvumą. Yra tyrimų, rodančių, kad IL-9 pelių modeliuose gali stabdyti melonomos augimą [38]. Už IL-9 koduojančio $I l 9$ geno nuskaitymą yra atsakingi transkripcijos faktoriai, kuriu svarbiausi STAT6 ir PU.1. Būtu tikslinga tirti STAT6 ir PU.1 transkripcijos faktoriụ raišką Th9 ląstelèse ir jụ sąsajas su IL-9 raiška alergine astma sergančiu asmenų periferiniame kraujyje. Tikètina, kad tyrimų rezultatai padés ne tik pagilinti astmos patogenezés žinias, bet ir nustatyti naujus gydymo taikinius, prisidès kuriant naujas astmos gydymo strategijas. 


\section{THE ROLE OF TH9 CELLS AND THEIR TRANSCRIPTION FACTORS STAT6 AND PU.1 IN ASTHMA}

\author{
IEVA JANULAITYTÉ, SIMONA LAVINSKIENE \\ DEPARTMENT OF PULMONOLOGY AND IMMUNOLOGY \\ ACADEMY OF MEDICINE LUHS
}

Keywords: asthma, Th9 cells, transcription factors, IL-9, STAT6, PU.1.

Summary. Asthma is a common chronic inflammatory disease of the airways characterized by variable and reccuring symptoms, reversible airflow obstruction and bronchospasm. Asthma is caused by a combination of complex and incompletely understood environmental and genetic interactions. Common symptoms include wheezing, coughing, chest tightness and shortness of breath. Th9 cells are novel identified subest of $\mathrm{CD}^{+} \mathrm{T}$ helper cells, which could contribute to airway inflammation in allergic asthma. Th9 cells are a distinct subpopulation of $\mathrm{CD}^{+}$ effector $\mathrm{T}$ cell that preferntially secretes high levels of IL-9. Naive $\mathrm{CD}^{+} \mathrm{T}$ cells differentiate into Th9 cells in the presence of TGF- $\beta$ and IL-4. These cytokines induce expression of the transcription factors PU.1 and STAT6 (by Interferon Regulatory Factor 4 (IRF4), which subsegently regulate expression of the $1 / 9$ gene. Th9 cells play important role in defense against parasitic helminth infections and allergic inflammation, airway remodeling, and autoimune disease.

\section{LITERATŪRA}

1. Bufford, J.D., et al., Effects of dog ownership in early childhood on immune development and atopic diseases. Clin Exp Allergy, 2008. 38(10): p. 1635-43.

2. Masoli, M., et al., The global burden of asthma: executive summary of the GINA Dissemination Committee report. Allergy, 2004. 59(5): p. 469-78.

3. Ciprandi, G., et al., Peripheral Th-17 cells in allergic rhinitis: New evidence. Int Immunopharmacol, 2010. 10(2): p. 226-9.

4. Lloyd, C.M. and E.M. Hessel, Functions of T cells in asthma: more than just TH2 cells. Nat Rev Immunol, 2010. 10(12): p. 838-848.

5. Barnes, P.J., Pathophysiology of allergic inflammation. Immunological Reviews, 2011. 242(1): p. 31-50.

6. Rothenberg, M.E., Eosinophilia. N Engl J Med, 1998. 338(22): p. 1592-600.

7. Horvath, G. and A. Wanner, Inhaled corticosteroids: effects on the airway vasculature in bronchial asthma. Eur Respir J, 2006. 27(1): p. 172-87.

8. Cher, D.J. and T.R. Mosmann, Two types of murine helper T cell clone. II. Delayed-type hypersensitivity is mediated by TH1 clones. J Immunol, 1987. 138(11): p. 3688-94.

9. Cherwinski, H.M., et al., Two types of mouse helper T cell clone. III. Further differences in lymphokine synthesis between Th1 and Th2 clones revealed by RNA hybridization, functionally monospecific bioassays, and monoclonal antibodies. J Exp Med, 1987. 166(5): p. 1229-44.

10. Jabeen, R. and M.H. Kaplan, The symphony of the ninth: the development and function of Th9 cells. Curr Opin Immunol, 2012. 24(3): p. 303-7.

11. Stassen, M., E. Schmitt, and T. Bopp, From interleukin-9 to T helper 9 cells. Ann N Y Acad Sci, 2012. 1247: p. 56-68.

12. Dardalhon, V., et al., IL-4 inhibits TGF-beta-induced Foxp3+ T cells and, together with TGF-beta, generates IL-9+ IL-10+ Foxp3(-) effector T cells. Nat Immunol, 2008. 9(12): p. 1347-55.

13. Staudt, V., et al., Interferon-regulatory factor 4 is essential for the developmental program of T helper 9 cells. Immunity, 2010. 33(2): p. 192-202.
14. Yao, W., R.S. Tepper, and M.H. Kaplan, Predisposition to the development of IL-9-secreting T cells in atopic infants. J Allergy Clin Immunol, 2011. 128(6): p. 1357-1360.e5

15. Putheti, P., et al., Human $C D 4<$ sup $>+</$ sup $>$ Memory T Cells Can Become CD4<sup $>+</$ sup $>$ IL-9<sup $>+</$ sup $>$ T Cells. PLoS ONE, 2010. 5(1): p. e8706

16. Ma, C.S., S.G. Tangye, and E.K. Deenick, Human Th9 cells: inflammatory cytokines modulate IL-9 production through the induction of IL-21. Immunol Cell Biol, 2010. 88(6): p. 621-623.

17. Goswami, R., et al., STAT6-dependent regulation of Th9 development. J Immunol, 2012. 188(3): p. 968-75.

18. Zhao, P., et al., IL-9 and Th9 cells: progress and challenges. Int Immunol, 2013. 25(10): p. 547-51.

19. Uyttenhove, C., R.J. Simpson, and J. Van Snick, Functional and structural characterization of P40, a mouse glycoprotein with T-cell growth factor activity. Proc Natl Acad Sci U S A, 1988. 85(18): p. 6934-8.

20. Van Snick, J., et al., Cloning and characterization of a cDNA for a new mouse T cell growth factor (P40). J Exp Med, 1989. 169(1): p. 363-8.

21. Hultner, L., et al., In activated mast cells, IL-1 up-regulates the production of several Th2-related cytokines including IL-9. J Immunol, 2000. 164(11): p. 5556-63.

22. Glimelius, I., et al., IL-9 expression contributes to the cellular composition in Hodgkin lymphoma. Eur J Haematol, 2006. 76(4): p. 278-83.

23. White, B., et al., Two first-in-human, open-label, phase I dose-escalation safety trials of MEDI-528, a monoclonal antibody against interleukin-9, in healthy adult volunteers. Clin Ther, 2009. 31(4): p. 728-40.

24. Gessner, A., H. Blum, and M. Rollinghoff, Differential regulation of IL-9-expression after infection with Leishmania major in susceptible and resistant mice. Immunobiology, 1993. 189(5): p. 419-35.

25. Faulkner, $\mathrm{H}_{\text {., }}$ et al., Interleukin- 9 enhances resistance to the intestinal nematode Trichuris muris. Infect Immun, 1998. 66(8): p. 3832-40.

26. Fallon, P.G., et al., Expression of interleukin-9 leads to Th2 cytokine-dominated responses and fatal enteropathy in mice with chronic Schistosoma mansoni infections. Infect Immun, 2000. 68(10): p. 6005-11.

27. Wong, M.T., et al., Regulation of human Th9 differentiation by type I interferons and IL-21. Immunol Cell Biol, 2010. 88(6): p. 624-31.

28. Lukacs, N.W., et al., C-C chemokine-induced eosinophil chemotaxis during allergic airway inflammation. Journal of Leukocyte Biology, 1996. 60(5): p. 573-8.

29. Li, L., et al., Effects of Th2 Cytokines on Chemokine Expression in the Lung: IL13 Potently Induces Eotaxin Expression by Airway Epithelial Cells. The Journal of Immunology, 1999. 162(5): p. 2477-2487.

30. Gonzalo, J.A., et al., The coordinated action of CC chemokines in the lung orchestrates allergic inflammation and airway hyperresponsiveness. J Exp Med, 1998. 188(1): p. 157-67.

31. Thomas, M.C. and C.M. Chiang, The general transcription machinery and general cofactors. Crit Rev Biochem Mol Biol, 2006. 41(3): p. 105-78.

32. Kaplan, M.H., et al., Impaired IL-12 responses and enhanced development of Th2 cells in Stat4-deficient mice. Nature, 1996. 382(6587): p. 174-7.

33. Chang, H.C., et al., The transcription factor PU.1 is required for the development of IL-9-producing T cells and allergic inflammation. Nat Immunol, 2010. 11(6): p. 527-34

34. Li, J., et al., Specific targeting and constitutive association of histone deacetylase complexes during transcriptional repression. Genes Dev, 2002. 16(6): p. 687-92.

35. Nowak, E.C., et al., IL-9 as a mediator of Th17-driven inflammatory disease. J Exp Med, 2009. 206(8): p. 1653-60.

36. Lu, L.F., et al., Mast cells are essential intermediaries in regulatory T-cell tolerance. Nature, 2006. 442(7106): p. 997-1002.

37. Melis, M., et al., Fluticasone induces apoptosis in peripheral T-lymphocytes: a comparison between asthmatic and normal subjects. Eur Respir J, 2002. 19(2): p. $257-66$.

38. Knoops, L. and J.C. Renauld, IL-9 and its receptor: from signal transduction to tumorigenesis. Growth Factors, 2004. 22(4): p. 207-15.

39. http://upload.wikimedia.org/wikipedia/commons/8/80/Transcription_Factors.svg 